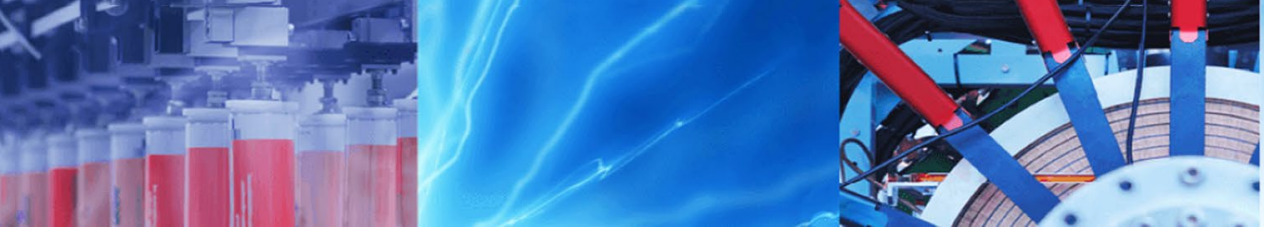

Research Article

\title{
Removal of cadmium (Cd-II) from aqueous solution using gas industry-based adsorbent
}

\author{
Praveen Kumar ${ }^{1,2} \cdot$ Pawan Kumar ${ }^{1}$
}

(c) Springer Nature Switzerland AG 2019

\begin{abstract}
The present study is to determine the potential of gas industry sludge as a low-cost adsorbent for the removal of cadmium from aqueous solution. The batch experiments were conducted to optimize $\mathrm{pH}$, contact time, adsorbent dose and initial metal ion concentration. The experiments were optimized at $\mathrm{pH} 5$, contact time $60 \mathrm{~min}$ and an adsorbent dose of $0.75 \mathrm{~g} / 100 \mathrm{ml}$ with constant agitation at the room temperature. The result of batch experiment was further discussed for the removal of cadmium from adsorbent. The adsorption data were correlated with Freundlich and Langmuir isotherms to know the interaction of sludge adsorbent with cadmium. High value of regression coefficient $\left(R^{2}>0.95\right)$ indicated that the adsorption data are fitted well with both Langmuir and Freundlich isotherms. The adsorption capacity of $25 \mathrm{mg} / \mathrm{g}$ was found to be quite good for removal of the cadmium from aqueous solution. Desorption efficiency showed highest removal with $\mathrm{HCl}(42.83 \%)$; followed by $\mathrm{HNO}_{3}(38.26 \%)$, EDTA (37.73\%) and $\mathrm{H}_{2} \mathrm{SO}_{4}(36.83 \%)$. The removal and desorption efficiency of the gas industry-based adsorbent was found to be comparable and even more suitable than the chemically modified adsorbents. The present study provides a low-cost and environmentally friendly adsorbent, which can be used as an alternative for the treatment of wastewater.
\end{abstract}

Keywords Adsorption isotherm $\cdot$ Batch reaction $\cdot$ Cadmium $\cdot$ Gas industry sludge $\cdot$ Heavy metals

\section{Introduction}

Heavy metal pollution is a major environmental concern at the global scenario and has limited the availability of fresh water for the increasing population [1,2]. The changing water quality has become a serious problem for the entire nations of the world [3]. The heavy metals are nonbiodegradable, cause damage along the trophic level and create serious problems due to their persistence, toxicity and bioaccumulation nature [4-7]. Some of the heavy metals are biologically essential and act as a micronutrient for plants and relatively harmless, but some are purely toxic (i.e. arsenic, beryllium, cadmium and lead). These include metallic elements having atomic weight in the range 63.5 and $200.6 \mathrm{~g} \mathrm{~mole}^{-1}$ with a specific gravity greater than $5 \mathrm{~g} \mathrm{~cm}^{-3}$ [8].

The heavy metals are contributed by different sources, and their high concentration may cause serious health hazards $[9,10]$. Cadmium (Cd-II) is one of the heavy metals having main sources such as the wastewater, industrial effluents, paint, plastic, synthetic fertilizer, metal coatings industry [11], atmospheric deposition and rocks [12]. This metal is very harmful, and the human being is susceptible from residential or occupational exposure even at very minute concentration $(0.5 \mathrm{mg} / \mathrm{L})$. High level of cadmium in the wastewater may lead to various ailments [13]. International Agency for Research on Cancer (IARC) has classified that the cadmium and its compounds are carcinogenic in nature [14]. The ingestion and inhalation of cadmium may

$\triangle$ Praveen Kumar, pk.hpkv@gmail.com | ${ }^{1}$ Department of Environmental Sciences, Central University of Himachal Pradesh, Dharamshala 176215, India. ${ }^{2}$ Department of Energy and Environmental Sciences, Chaudhary Devi Lal University, Sirsa, Haryana 125055, India. 
cause dysfunction of the kidney and severe damage to the lungs; and instead, its chronic exposure may lead to death $[1,15]$. A high proportion of cadmium in the soil may produce oxidative stress and nutritional deficiencies [16-18].

The wastewater treatment has become a worldwide problem and concern for the policy makers and environmentalists [19]. Various conventional physiochemical processes are used for the removal of heavy metals from wastewater such as coagulation, flocculation [20], precipitation [21], adsorption [22], membrane filtration [23], electrolysis [24], photocatalytic degradation [25], ion exchange [26], oxidation, reduction [27] and solvent extraction [28]. Different researchers have indicated the strength and limitation of these techniques [1, 29-31]. Among these, adsorption method does not require a huge input of chemical reagents that create other environmental and health problems to deal with secondary pollutants. Adsorption studies have investigated the lowcost adsorbents from agricultural and industrial wastes and found them to be much effective for the removal of heavy metals from wastewater [32-34]. Some of these studies modified the adsorbents with various chemicals to increase the sorption capacity $[29,35,36]$, but still there is a stringent need to explore low-cost and high-potential adsorbent that could have appreciable removal efficiency and desorption capacity for the recovery of heavy metals from the wastewater.

In the present study, the gas industry sludge has been used without any chemical treatment to prepare gas industry-based adsorbent (GIBA), which was further used in a batch experiment for the removal of cadmium (Cd-II) from aqueous solution. The study covered a series of batch experiments for the optimization of $\mathrm{pH}$, contact time, adsorbent dose and initial metal ion concentration; followed by the desorption process to check the reusability of adsorbent for further use. The Langmuir and Freundlich isotherms were used to describe the adsorption of Cd-II on the adsorbent. Thus, the present study aims to explore the potential of gas industry sludge for the removal of heavy metal from synthetic solution of cadmium. The adsorption isotherm provides input to better understand the interaction of adsorbate on the adsorbent that can further be helpful to design the batch system for wastewater treatment.

\section{Materials and methods}

\subsection{Preparation of gas industry-based adsorbent (GIBA)}

The sludge samples were collected from Indraprastha Gas Limited, New Delhi, India. The samples were transported to the laboratory and kept in oven at $103^{\circ} \mathrm{C}$ for $24 \mathrm{~h}$ and thereafter grinded using agate mortar. Then the samples were sieved, marked as gas industry-based adsorbent and stored in desiccator.

\subsection{Preparation of synthetic solution of cadmium for batch reaction and optimization}

The stock solution of $\mathrm{Cd}-\mathrm{II}(1000 \mathrm{mg} / \mathrm{L})$ was prepared by dissolving cadmium chloride $\left(\mathrm{CdCl}_{2} \cdot \mathrm{H}_{2} \mathrm{O}\right)$ in double-distilled water and further diluted to prepare different solutions of various concentrations. The batch experiment was conducted to check the influence of $\mathrm{pH}$, adsorbent dose, contact time and initial metal ion concentration (Cd-II) on adsorption efficiency. In case of $\mathrm{pH}$ optimization, the stock solution $(100 \mathrm{mg} / \mathrm{L})$ was taken in titration flask and $\mathrm{pH}$ was adjusted in the range of 2-7 using $0.1 \mathrm{~N} \mathrm{HCl}$ and $0.1 \mathrm{~N} \mathrm{NaOH}$ and calibrated with buffer solutions $(\mathrm{pH} 4.0$, 7.0, 9.2). The experiment was conducted in a fixed adsorbent dose of $1.0 \mathrm{~g} / \mathrm{L}$, and the stock solution was agitated using orbital shaker at $150 \mathrm{rpm}$ for $3 \mathrm{~h}$ and constant temperature $\left(30 \pm 2^{\circ} \mathrm{C}\right)$. Finally, the solution was centrifuged at $4000 \mathrm{rpm}$ for $15 \mathrm{~min}$; and after filtration, the supernatant was taken to check the residual concentration of cadmium (Cd-II) with the help of atomic absorption spectrophotometer (Lab India AA-7000 series). The removal efficiency (\%) of $\mathrm{Cd}$-II was determined [37] using following equation (Eq. 1):

Removal efficiency $(\%)=\left(\frac{C_{0}-C_{1}}{C_{0}}\right) \times 100$,

where $C_{0}$ represents the initial concentration of $C d-I I$ and $C_{1}$ corresponds to its final concentration after the batch experiment. The optimized $\mathrm{pH}$ obtained from the above experiment was used to check the effect of contact time (15-180 $\mathrm{min}$ ) and adsorbent dose (2.5-12.5 g/L). In the last run of batch experiment, the removal efficiency of $\mathrm{Cd}-\mathrm{II}$ was checked using optimum $\mathrm{pH}$, adsorbent dose and contact time with varied concentrations $(20-200 \mathrm{mg} / \mathrm{L})$ of $\mathrm{Cd}-\mathrm{Il}$ in aqueous solution, while the speed of orbital shaker $(150 \mathrm{rpm})$ and the temperature $\left(30 \pm 2^{\circ} \mathrm{C}\right)$ of the working environment were kept constant. Removal efficiency was calculated using a formula (Eq. 1) as stated above, and the uptake capacity of the Cd-II was also calculated using Eq. 2 as [38]:

$Q_{\mathrm{up}}(\mathrm{mg} / \mathrm{L})=\frac{v\left(C_{0}-C_{f}\right)}{M}$,

where $Q_{\text {up }}$ is the uptake capacity of $\mathrm{Cd}$-II adsorbed on the GIBA, $C_{0}$ is the initial concentration $(\mathrm{mg} / \mathrm{L})$ of the $\mathrm{Cd}-\mathrm{Il}$ in aqueous solution and $C_{f}$ is the final concentration of the 
Cd-II after using $v$ (volume) of the metal solution ( $L$ ) with $M$ (mass) of adsorbent $(g)$ used in the experiment.

\subsection{Desorption study}

Desorption studies were carried out to check the reusability of GIBA with respect to four desorbing agents such as $\mathrm{HCl}, \mathrm{H}_{2} \mathrm{SO}_{4}, \mathrm{HNO}_{3}$ and EDTA; all having same molarity $(0.1 \mathrm{M})$. Cd-II-loaded adsorbent $(1 \mathrm{~g})$ was taken within a desorbing agent $100 \mathrm{ml}(0.1 \mathrm{M})$ using 250-ml Erlenmeyer flask, and a contact time of 30 min was applied with a stirring rate of $150 \mathrm{rpm}$ at constant temperature $\left(30 \pm 2^{\circ} \mathrm{C}\right)$. Desorption efficiency was calculated [39] using Eq. 3 as:

Desorption efficiency $=\frac{\text { Amount of metal ion desorbed }}{\text { Amount of metal ion adsorbed }} \times 100$

\section{Results and discussion}

\section{1 pH optimization}

The adsorption of cadmium ( $\mathrm{Cd}-\mathrm{II})$ using GIBA in the present study was found to be varied at different $\mathrm{pH}$ levels, which has also been reported by many researchers using different types of adsorbents $[12,40,41]$. The $\mathrm{pH}$ value was optimized for the present batch experiment. The per cent removal and uptake capacity $(\mathrm{mg} / \mathrm{g})$ at different $\mathrm{pH}$ levels are shown in Fig. 1. There is an increase in removal and uptake capacities of $\mathrm{Cd}-\mathrm{Il}$ up to $\mathrm{pH}$ level of 5 . The per cent removal and uptake capacity at this $\mathrm{pH}$ value were found to be $85.69 \%$ and $88.07 \mathrm{mg} / \mathrm{g}$, respectively. There was no appreciable change in the uptake and removal capacities that helped to select optimum $\mathrm{pH} \mathrm{5}$, and thereafter, the increasing $\mathrm{pH}$ level was considered less economically

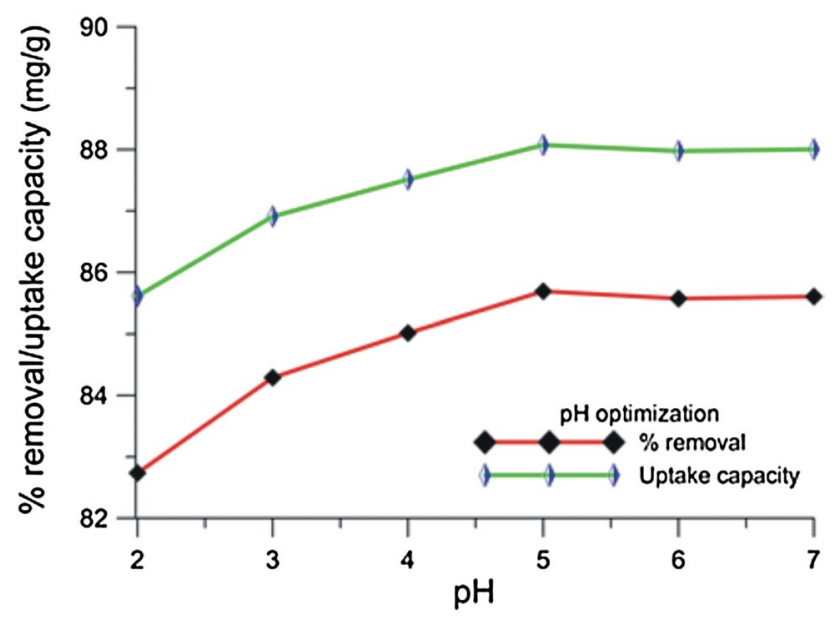

Fig. 1 Effect of pH on per cent removal and uptake capacity of cadmium viable. Adsorption studies conducted by many researchers with cadmium also showed optimization level close to $\mathrm{pH}$ $5.0[32,42-44]$.

\subsection{Effect of adsorbent dose and contact time}

To study the effect of adsorbent dose and contact time, the batch experiment was conducted at initial cadmium concentration of $100 \mathrm{mg} / \mathrm{L}$, optimized $\mathrm{pH}(5)$, temperature $\left(30^{\circ} \mathrm{C}\right)$ and agitation speed $(150 \mathrm{rpm})$. The adsorbent dose was found to be varied from 0.25 to $1.25 \mathrm{~g} / 100 \mathrm{ml}$ and contact time from 15 to $180 \mathrm{~min}$, respectively. The result revealed that the adsorption rate increased from 83.761 to $87.215 \%$, when contact time was increased from 15 to $180 \mathrm{~min}$ at the adsorbent dose of $0.25 \mathrm{~g} / 100 \mathrm{ml}$. Also in the similar time frame, an increase in per cent removal was observed from 85.021 to $91.345 \%, 86.575$ to $91.760 \%$, 87.32 to $92.93 \%$ and 88.542 to $93.070 \%$ at $0.50,0.75,1.00$ and $1.25 \mathrm{~g} / 100 \mathrm{ml}$ dose of adsorbent, respectively (Fig. 2). Figure 3 shows that the uptake capacity increased from 33.504 to $34.886 \mathrm{mg} / \mathrm{g}, 17.004$ to $18.151 \mathrm{mg} / \mathrm{g}, 11.543$ to $12.235 \mathrm{mg} / \mathrm{g}, 8.73$ to $9.29 \mathrm{mg} / \mathrm{g}$ and 7.083 to $7.446 \mathrm{mg} / \mathrm{g}$ at $0.25,0.50,0.75,1.00$ and $1.25 \mathrm{~g} / 100 \mathrm{ml}$ dose of adsorbent, respectively, when contact time was increased from 15 to $180 \mathrm{~min}$. There was no appreciable increase in the removal per cent for cadmium after $60 \mathrm{~min}$.

It was observed that the per cent removal of cadmium from aqueous solution increased with increase in adsorbent dose from 0.25 to $0.75 \mathrm{~g} / 100 \mathrm{ml}$. However, such an increase in per cent removal was not observed after increasing the adsorbent dose. This was due to "solid concentration" effect, which explains that the quantity of a metal adsorbed per unit quantity of adsorbent decreases significantly with increasing the mass

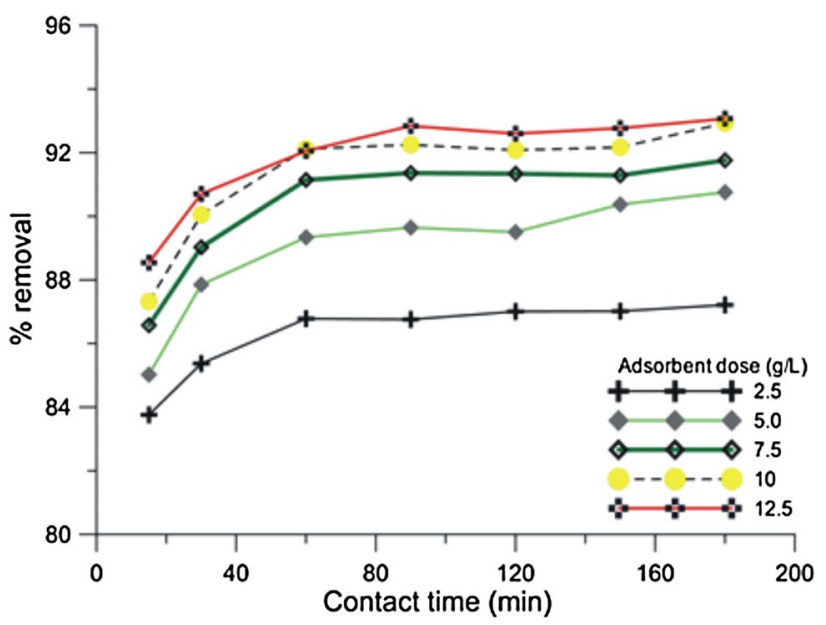

Fig. 2 Effect of adsorbent dose and contact time on cadmium removal by gas industry-based adsorbent 
(a)

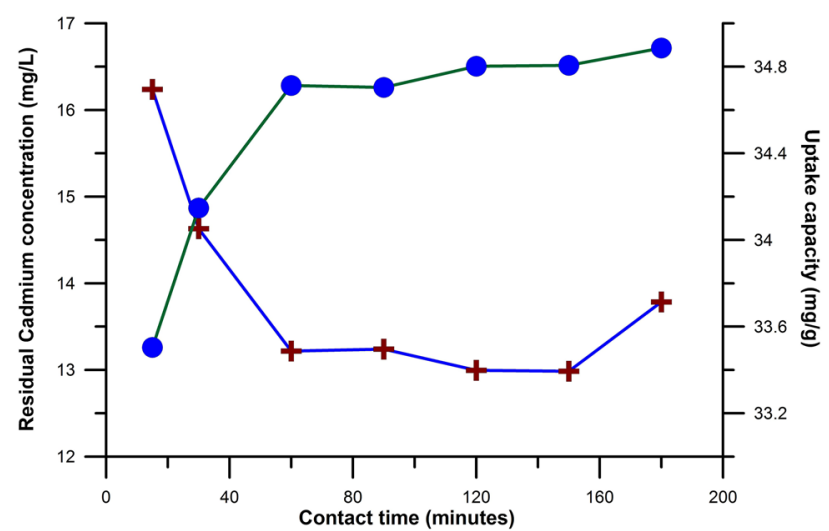

(c)

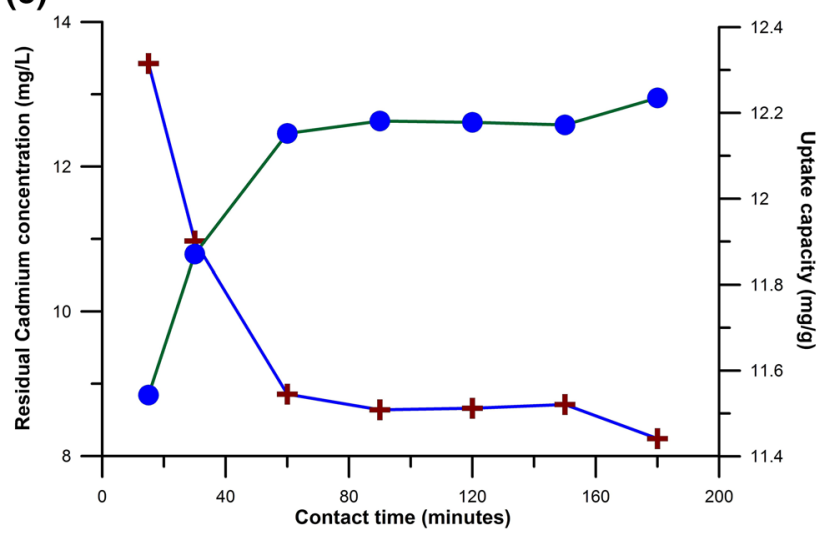

(e)

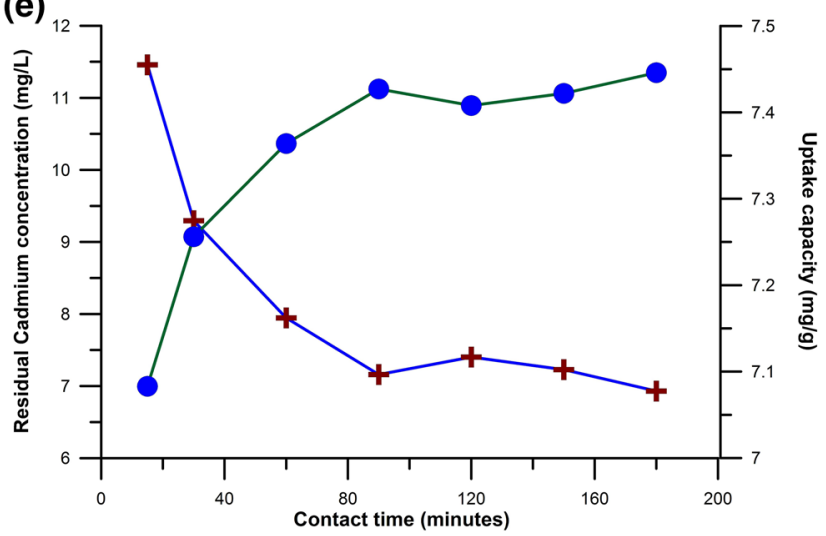

(b)

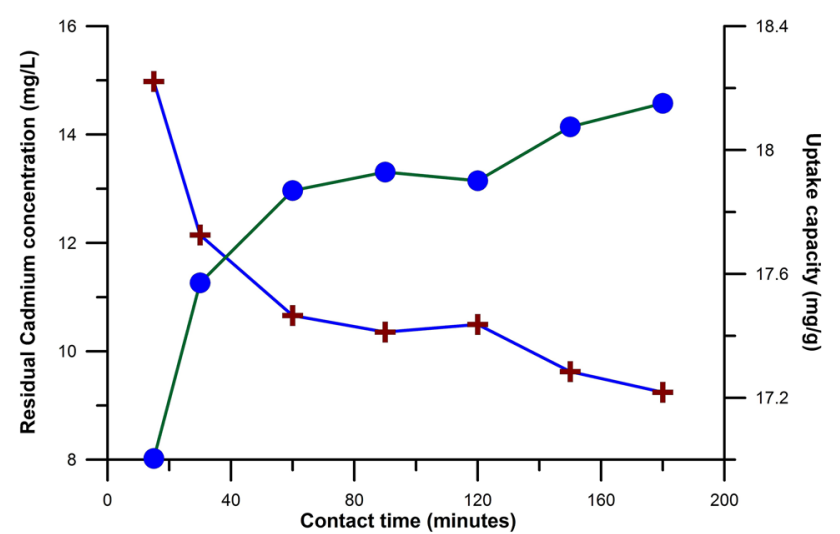

(d)
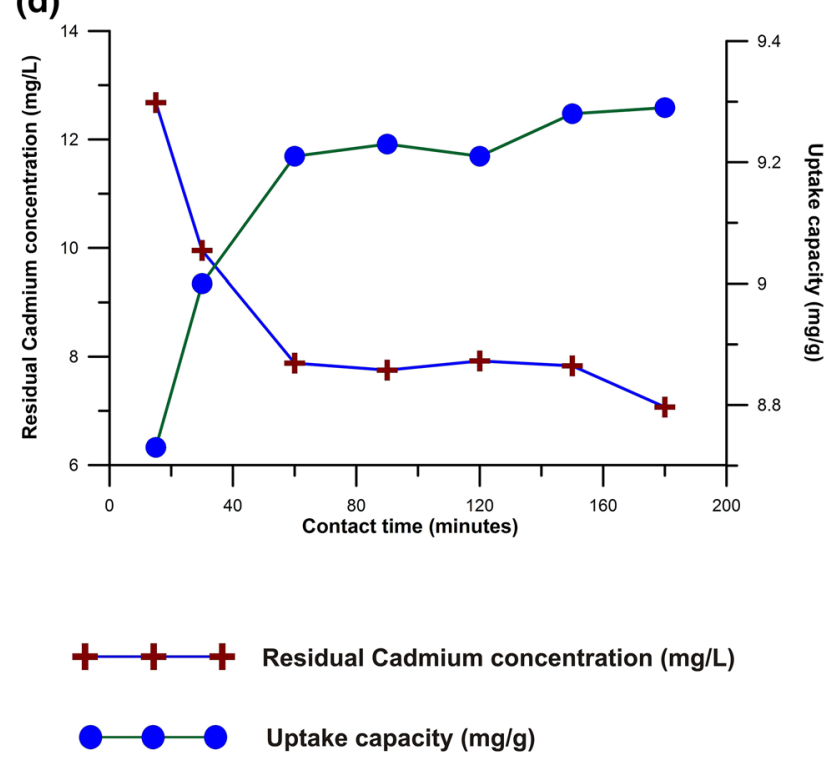

Fig. 3 Effect of contact time on removal and uptake capacities from gas industry-based adsorbent

of adsorbent per unit volume [45]. It was observed that the concentration of cadmium adsorbed on the gas industry-based adsorbent increased with time. During the initial stage of sorption, a large number of vacant sites were available for adsorption. It was also observed that with the increase in adsorbent dose, more surface area became available for adsorption due to increase in active sites on the adsorbent; then making easier penetration of metal ions to the adsorption sites [46]. After a lapse of time, the remaining vacant surface sites occupied difficulty due to repulsive forces between the solute molecules on the adsorbent surface.

\subsection{Effect of initial cadmium concentration}

To study the effect of initial metal ion concentration, the optimized value of $\mathrm{pH}(5.0)$, contact time (180 min) and adsorbent dose $(0.75 \mathrm{~g} / 100 \mathrm{ml})$ were used in batch experiment. The cadmium concentration increased from 20 to $200 \mathrm{mg} / \mathrm{L}$, and the per cent removal decreased from 
Table 1 Effect of initial cadmium concentration on the per cent removal and uptake capacity of cadmium by gas industry-based adsorbent

\begin{tabular}{llllc}
\hline $\begin{array}{l}\text { Cadmium concen- } \\
\text { tration }(\mathrm{mg} / \mathrm{L})\end{array}$ & $\begin{array}{l}\text { Residual cadmium con- } \\
\text { centration }(\mathrm{mg} / \mathrm{L})\end{array}$ & $\begin{array}{l}\text { Removed cadmium } \\
\text { concentration }(\mathrm{mg} / \mathrm{L})\end{array}$ & \% removal & $\begin{array}{l}\text { Uptake } \\
\text { capacity } \\
(\mathrm{mg} / \mathrm{g})\end{array}$ \\
\hline 20 & 0.153 & 19.847 & 99.24 & 2.646 \\
40 & 1.853 & 38.147 & 95.37 & 5.086 \\
60 & 3.229 & 56.771 & 94.62 & 7.569 \\
80 & 6.124 & 73.876 & 92.35 & 9.850 \\
100 & 9.214 & 90.786 & 90.79 & 12.104 \\
150 & 20.55 & 129.45 & 86.30 & 17.260 \\
200 & 36.85 & 163.15 & 81.58 & 21.753 \\
\hline
\end{tabular}

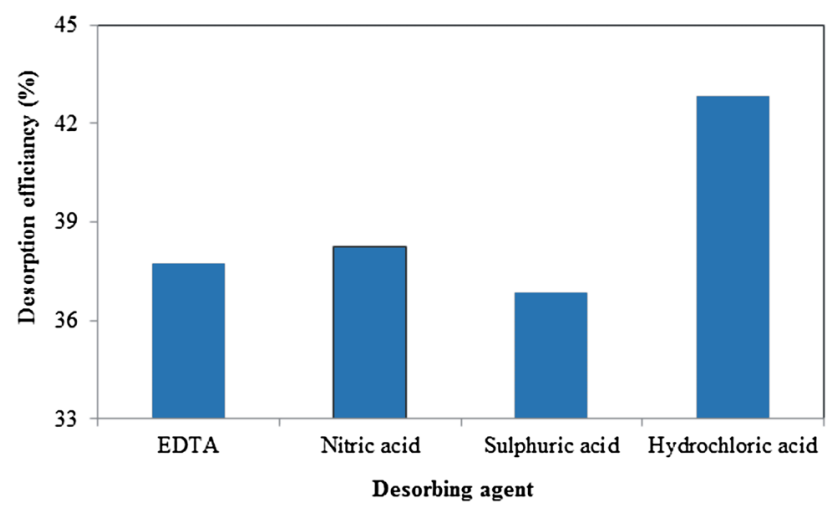

Fig. 4 Desorption efficiency of various desorbing agents for the removal of $\mathrm{Cd}$-II from gas industry-based adsorbent

99.24 to $81.58 \%$, whereas the uptake capacity increased from 2.646 to $21.753 \mathrm{mg} / \mathrm{g}$ (Table 1). This is because of more binding sites were available at a low concentration of metal ions, but as the concentration of metal ions increased, then the ions started to compete for available binding sites [47].

\subsection{Desorption study}

Recovery of metal ions adsorbed on the adsorbent is one the most important aspects for the development of a successful adsorption process [48]. The maximum desorption efficiency was observed to be $42.83 \%$ with gas industry sludge-based adsorbent using $0.1 \mathrm{M} \mathrm{HCl}$ as eluent (Fig. 4). The desorption efficiency of adsorbent for cadmium was found to be in the following order as $\mathrm{HCl}>\mathrm{HNO}_{3}>$ EDTA $>\mathrm{H}_{2} \mathrm{SO}_{4}$.

\subsection{Adsorption isotherm}

The adsorption isotherm represents the relationship between the concentration of the solute in the adsorbent $\left(q_{\mathrm{e}}\right)$ and solution at equilibrium $\left(C_{\mathrm{e}}\right)$ [49]. Adsorption

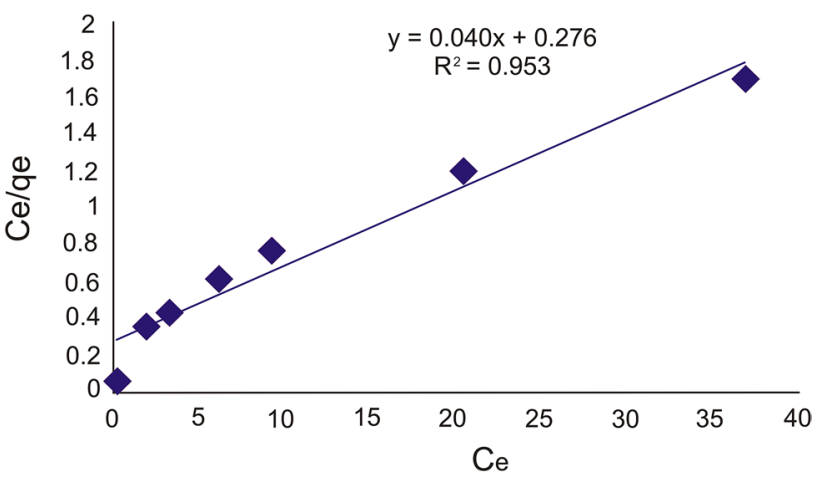

Fig. 5 Langmuir adsorption isotherm for cadmium by gas industrybased adsorbent

capacities were calculated from linearized Langmuir isotherm using Eq. 4 :

$C_{\mathrm{e}} / q_{\mathrm{e}}=1 / q_{\max } b+C_{\mathrm{e}} / q_{\max }$

where $C_{\mathrm{e}}$ is the concentration of adsorbate solution at equilibrium and $q_{\mathrm{e}}$ is amount adsorbed per unit of adsorbent at equilibrium. The Langmuir isotherm considers that all of the metal ions are chemically adsorbed in a fixed number on those free sites, which are energetically equivalent [50]. The Freundlich isotherm [51] was also used to express the linearized logarithmic (Eq. 5) as:

$\log q_{\mathrm{e}}=(1 / n) \log C_{\mathrm{e}}+\log K_{\mathrm{f}}$

where $q_{\mathrm{e}}$ is the amount of metal adsorbed in $(\mathrm{mg} / \mathrm{g})$ and $K_{\mathrm{f}}$ and $1 / n$ are the relative indicators of the adsorption capacity. The Langmuir and Freundlich isotherms are plotted in Figs. 5 and 6, which indicated the value of $R^{2}>0.95$. The equilibrium biosorption data followed both Langmuir and Freundlich isotherms with $R^{2}>0.95$ (Table 2). The maximum cadmium adsorption capacity $\left(q_{\max }\right)$ with gas industry-based adsorbent was found to be $25 \mathrm{mg} / \mathrm{g}$. The present study was further compared with other studies, which indicated that the GIBA is having appreciable adsorption capacity in comparison with the biosorbent materials and chemically modified adsorbents (Table 3 ). 


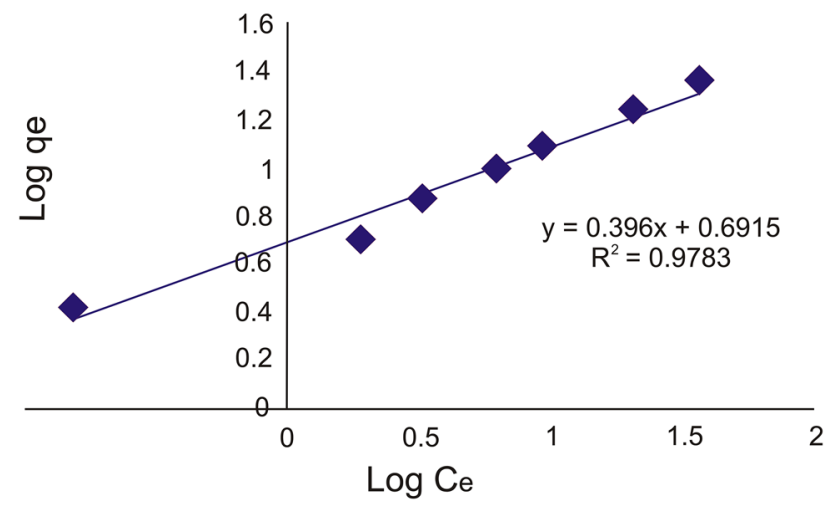

Fig. 6 Freundlich adsorption isotherm for cadmium by gas industry-based adsorbent

Table 2 Langmuir and Freundlich constant for cadmium by gas industry-based adsorbent

\begin{tabular}{llllllll}
\hline \multicolumn{2}{l}{ Langmuir constant } & & & \multicolumn{3}{l}{ Freundlich constant } \\
\cline { 1 - 2 }$q_{\max }(\mathrm{mg} / \mathrm{g})$ & $b(\mathrm{~L} / \mathrm{mg})$ & $R^{2}$ & & $K_{\mathrm{f}}(\mathrm{mg} / \mathrm{g})$ & $n(\mathrm{~L} / \mathrm{mg})$ & $R^{2}$ \\
\hline 25 & 0.14 & 0.953 & & 4.90 & 2.52 & 0.978 \\
\hline
\end{tabular}

The batch experiment further revealed that the GIBA is having high removal potential of heavy metal (Cd-II) and can be considered as a low-cost adsorbent for the wastewater treatment.

\section{Conclusion}

A wide range of adsorbents are used worldwide for the wastewater treatment; however, a search for the lowcost and environmentally friendly adsorbent is still there. Many researchers have inferred the alternative low-cost adsorbents including agricultural and industrial wastes, which can be potentially used for the removal and recovery of the heavy metals. The present study explored the potential of gas industry-based adsorbent (GIBA) in batch experiment after the optimization of various adsorption parameters such as $\mathrm{pH}$, contact time, adsorbent dose and effect of initial $\mathrm{Cd}$-II concentration from the aqueous solution. The adsorption capacity of present adsorbent is found to be very high in comparison to the agricultural byproducts and chemically modified adsorbents as well as biosorption. The high removal and desorption efficiency of GIBA from the aqueous solution strengthen its future use as a low-cost adsorbent for the removal of heavy metals from the wastewater.

Acknowledgements The authors acknowledge the Department of Energy and Environmental Sciences, Chaudhary Devi Lal University, Sirsa, Haryana, India, for providing resource facilities and laboratory analysis.

\section{Compliance with ethical standards}

Conflict of interest All the authors declare that they have no conflict of interest.

\section{References}

1. Fu F, Wang Q (2011) Removal of heavy metal ions from wastewaters: a review. J Environ Manag 92(3):407-418. https://doi. org/10.1016/j.jenvman.2010.11.011

2. Aji MP, Wiguna PA, Karunawan J, Wati AL (2017) Removal of heavy metal nickel-ions from wastewaters using carbon nanodots from frying oil. Procedia Eng 170:36-40. https://doi. org/10.1016/j.proeng.2017.03.007

3. Kumar P, Mahajan AK, Meena NK (2019) Evaluation of trophic status and its limiting factors in the Renuka Lake of Lesser Himalaya, India. Environ Monit Assess 191(2):105. https://doi. org/10.1007/s10661-019-7247-0
Table 3 Comparison of adsorption capacity $\left(q_{\max }\right)$ of gas industry-based adsorbent with other adsorbents for the removal of cadmium

\begin{tabular}{lllll}
\hline Sr. no. & Adsorbent type & $\mathrm{pH}$ & {$\left[q_{\max }(\mathrm{mg} / \mathrm{g})\right]$} & References \\
\hline 1 & Mucor rouxii & $4-5$ & 8.5 & Yan et al. [52] \\
2 & Gracilaria salicornia (red algae) & 5 & 18.0 & Hashim and Chu [53] \\
3 & Clarified sludge & - & 36.23 & Naiya et al. [49] \\
4 & Almond shell & $5-6$ & 7.19 & Mehrasbi et al. [54] \\
5 & Iron oxide-coated sludge & - & 14.7 & Phuengprasop et al. [34] \\
6 & Sodium bicarbonate-treated newspaper pulp & 6.4 & 1.44 & Ossman and Mansour [55] \\
7 & Natural phosphate & 5 & 26 & Yaacoubi et al. [56] \\
8 & Zeolite clinoptilolite & 4 & 16.73 & Dstan and Dehghani [57] \\
9 & Anacyclus nigllifolius Boiss & 6 & 69.14 & Mohammad et al. [58] \\
10 & Barley straw biochar & 6 & 1.6 & Jazini et al. [59] \\
11 & Caulerpa lentillifera & 5 & 4.7 & Pavasant et al. [60] \\
12 & Gas industry sludge-based adsorbent & 5 & 25.0 & Present study \\
\hline
\end{tabular}


4. Tao Y, Yuan Z, Xiaona H, Wei M (2012) Distribution and bioaccumulation of heavy metals in aquatic organisms of different trophic levels and potential health risk assessment from Taihu lake, China. Ecotoxicol Environ Saf 81:55-64. https://doi. org/10.1016/j.ecoenv.2012.04.014

5. Jain M, Garg VK, Kadirvelu K (2013) Cadmium (II) sorption and desorption in a fixed bed column using sunflower waste carbon calcium-alginate beads. Biores Technol 129:242-248. https:// doi.org/10.1016/j.biortech.2012.11.036

6. Qiu YW (2015) Bioaccumulation of heavy metals both in wild and mariculture food chains in Daya Bay, South China. Estuar Coast Shelf Sci 163:7-14. https://doi.org/10.1016/j.ecss.2015.05.036

7. Vakili M, Rafatullah M, Ibrahim MH, Abdullah AZ, Salamatinia B, Gholami Z (2014) Oil palm biomass as an adsorbent for heavy metals. Rev Environ Contam Toxicol 232:61-88. https://doi. org/10.1007/978-3-319-06746-9-3

8. Srivastava NK, Majumder CB (2008) Novel biofiltration methods for the treatment of heavy metals from industrial wastewater. J Hazard Mater 151(1):1-8. https://doi.org/10.1016/j.jhazm at.2007.09.101

9. Gaury PK, Meena NK, Mahajan AK (2018) Hydrochemistry and water quality of Rewalsar Lake of Lesser Himalaya, Himachal Pradesh, India. Environ Monit Assess 190(2):84. https://doi. org/10.1007/s10661-017-6451-z

10. Sarkar S, Prakasam M, Banerji US, Bhushan R, Gaury PK, Meena NK (2016) Rapid sedimentation history of Rewalsar Lake, Lesser Himalaya, India during the last fifty years - Estimated using ${ }^{137} \mathrm{Cs}$ and ${ }^{210} \mathrm{~Pb}$ dating techniques: a comparative study with other North-Western Himalayan Lakes. Himal Geol 37(1):1-7

11. Martin S, Griswold W (2009) Human health effects of heavy metals. Environ Sci Technol Briefs Citiz 15:1-6

12. Rafatullah M, Sulaiman O, Hashim R, Ahmad A (2012) Removal of cadmium (II) from aqueous solutions by adsorption using meranti wood. Wood Sci Technol 46(1-3):221-241. https://doi. org/10.1007/s00226-010-0374-y

13. Flora SJS, Mittal M, Mehta A (2008) Heavy metal induced oxidative stress and its possible reversal by chelation therapy. Indian J Med Res 128(4):501

14. Henson MC, Chedrese PJ (2004) Endocrine disruption by cadmium, a common environmental toxicant with paradoxical effects on reproduction. Exp Biol Med 229(5):383-392. https:// doi.org/10.1177/153537020422900506

15. Babel S, Kurniawan TA (2003) Low-cost adsorbents for heavy metals uptake from contaminated water: a review. J Hazard Mater 97(1-3):219-243. https://doi.org/10.1016/S0304 -3894(02)00263-7

16. Satarug S, Garrett SH, Sens MA, Sens DA (2009) Cadmium, environmental exposure, and health outcomes. Environ Health Perspect 118(2):182-190. https://doi.org/10.1289/ehp.0901234

17. Irfan M, Hayat S, Ahmad A, Alyemeni MN (2013) Soil cadmium enrichment: allocation and plant physiological manifestations. Saudi J Biol Sci 20(1):1-10. https://doi.org/10.1016/j. sjbs.2012.11.004

18. Jaishankar M, Mathew BB, Shah MS, Murthy KTP, Gowda KRS (2014) Biosorption of few heavy metal ions using agricultural wastes. J Environ Pollut Hum Health 2(1):1-6. https://doi. org/10.12691/jephh-2-1-1

19. Jain M, Garg VK, Kadirvelu K, Sillanpaa M (2016) Adsorption of heavy metals from multi-metal aqueous solution by sunflower plant biomass-based carbons. Int J Environ Sci Technol 13(2):493-500. https://doi.org/10.1007/s13762-015-0855-5

20. Johnson PD, Girinathannair P, Ohlinger KN, Ritchie S, Teuber L, Kirby J (2008) Enhanced removal of heavy metals in primary treatment using coagulation and flocculation. Water Environ Res 80(5):472-479. https://doi.org/10.2175/106143007X221490
21. Chen Q, Luo Z, Hills C, Xue G, Tyrer M (2009) Precipitation of heavy metals from wastewater using simulated flue gas: sequent additions of fly ash, lime and carbon dioxide. Water Res 43(10):2605-2614. https://doi.org/10.1016/j.watres.2009.03.007

22. Salam OEA, Reiad NA, EIShafei MM (2011) A study of the removal characteristics of heavy metals from wastewater by low-cost adsorbents. J Adv Res 2(4):297-303. https://doi. org/10.1016/j.jare.2011.01.008

23. Blocher C, Dorda J, Mavrov V, Chmiel H, Lazaridis NK, Matis KA (2003) Hybrid flotation-membrane filtration process for the removal of heavy metal ions from wastewater. Water Res 37(16):4018-4026. https://doi.org/10.1016/S0043 $-1354(03) 00314-2$

24. Moraes PB, Bertazzoli R (2005) Electro-degradation of landfill leachate in a flow electrochemical reactor. Chemosphere 58(1):41-46. https://doi.org/10.1016/j.chemospher e.2004.09.026

25. Lin WY, Wei C, Rajeshwar K (1993) Photocatalytic reduction and immobilization of hexavalent chromium at titanium dioxide in aqueous basic media. J Electrochem Soc 140(9):2477-2482. https://doi.org/10.1149/1.2220847

26. Burakov AE, Galunin EV, Burakova IV, Kucherova AE, Agarwal S, Tkachev AG, Gupta VK (2018) Adsorption of heavy metals on conventional and nanostructured materials for wastewater treatment purposes: a review. Ecotoxicol Environ Saf 148:702712. https://doi.org/10.1016/j.ecoenv.2017.11.034

27. Ahmad T, Rafatullah M, Ghazali A, Sulaiman O, Hashim R (2011) Oil palm biomass-Based adsorbents for the removal of water pollutants: a review. J Environ Sci Health Part C 29(3):177-222. https://doi.org/10.1080/10590501.2011.601847

28. Ahmad T, Danish $M$, Rafatullah $M$, Ghazali A, Sulaiman O, Hashim R, Ibrahim MN (2012) The use of date palm as a potential adsorbent for wastewater treatment: a review. Environ Sci Pollut Res 19(5):1464-1484. https://doi.org/10.1007/s11356-011-0709-8

29. Ngah WW, Hanafiah MAKM (2008) Removal of heavy metal ions from wastewater by chemically modified plant wastes as adsorbents: a review. Biores Technol 99(10):3935-3948. https://doi. org/10.1016/j.biortech.2007.06.011

30. Barakat MA (2011) New trends in removing heavy metals from industrial wastewater. Arab J Chem 4(4):361-377. https://doi. org/10.1016/j.arabjc.2010.07.019

31. Keng PS, Lee SL, Ha ST, Hung YT, Ong ST (2014) Removal of hazardous heavy metals from aqueous environment by low-cost adsorption materials. Environ Chem Lett 12(1):15-25. https:// doi.org/10.1007/s10311-013-0427-1

32. Zhai Y, Wei X, Zeng G, Zhang D, Chu K (2004) Study of adsorbent derived from sewage sludge for the removal of $\mathrm{Cd}^{2+}, \mathrm{Ni}^{2+}$ in aqueous solutions. Sep Purif Technol 38(2):191-196. https://doi. org/10.1016/j.seppur.2003.11.007

33. Sassi M, Bestani B, Said AH, Benderdouche N, Guibal E (2010) Removal of heavy metal ions from aqueous solutions by a local dairy sludge as a biosorbant. Desalination 262(1-3):243-250. https://doi.org/10.1016/j.desal.2010.06.022

34. Phuengprasop T, Sittiwong J, Unob F (2011) Removal of heavy metal ions by iron oxide coated sewage sludge. J Hazard Mater 186(1):502-507. https://doi.org/10.1016/j.jhazmat.2010.11.065

35. Argun ME, Dursun S (2006) Removal of heavy metal ions using chemically modified adsorbents. J Int Environ Appl Sci 1(1-2):27-40

36. Kumar U, Bandyopadhyay M (2006) Sorption of cadmium from aqueous solution using pretreated rice husk. Biores Technol 97(1):104-109. https://doi.org/10.1016/j.biortech.2005.02.027

37. Attar K, Demey H, Bouazza D, Sastre AM (2019) Sorption and desorption studies of $\mathrm{Pb}$ (II) and $\mathrm{Ni}$ (II) from aqueous solutions by a new composite based on alginate and magadiite materials. Polymers 11(2):340. https://doi.org/10.3390/polym11020340 
38. Al-Rub FAA, El-Naas MH, Benyahia F, Ashour I (2004) Biosorption of nickel on blank alginate beads, free and immobilized algal cells. Process Biochem 39(11):1767-1773. https://doi. org/10.1016/j.procbio.2003.08.002

39. Kannan A, Thambidurai S (2008) Comparative studies on the removal of nickel (II) from aqueous solution by using carbon derived from palmyra palm fruit seeds and commercial activated carbon. Int J Sci Technol 1(1):93-107

40. Sawyer CN, McCarty PL, Parkin GF (2002) Chemistry of environmental engineering, 5th edn. McGraw- Hill, New York

41. Zhou R, Zhou R, Zhang X, Tu S, Yin Y, Yang S, Ye L (2016) An efficient bio-adsorbent for the removal of dye: adsorption studies and cold atmospheric plasma regeneration. J Taiwan Inst Chem Eng 68:372-378. https://doi.org/10.1016/j.jtice.2016.09.030

42. Hammaini A, Gonzalez F, Ballester A, Blazquez ML, Munoz JA (2007) Biosorption of heavy metals by activated sludge and their desorption characteristics. J Environ Manag 84(4):419-426. https://doi.org/10.1016/j.jenvman.2006.06.015

43. Vazquez G, Gonzalez J, Freire M, Calvo M, Antorrena G (2009) Determination of the optimal conditions for the adsorption of cadmium ions and phenol on chestnut (Castanea sativa) shell. Globa NEST J 11(2):196-204. https://doi.org/10.30955/gnj.000587

44. Celekli A, Bozkurt H (2011) Bio-sorption of cadmium and nickel ions using Spirulina platensis: kinetic and equilibrium studies. Desalination 275(1-3):141-147. https://doi.org/10.1016/j.desal 2011.02.043

45. McKinley JP, Jenne EA (1991) Experimental investigation and review of the "solids concentration" effect in adsorption studies. Environ Sci Technol 25(12):2082-2087. https://doi.org/10.1021/ es00024a015

46. Azouaou N, Sadaoui Z, Djaafri A, Mokaddem H (2010) Adsorption of cadmium from aqueous solution onto untreated coffee grounds: equilibrium, kinetics and thermodynamics. J Hazard Mater 184(1-3):126-134. https://doi.org/10.1016/j.jhazm at.2010.08.014

47. Gupta R, Mohapatra H (2003) Microbial biomass: an economical alternative for removal of heavy metals from waste water. Indian J Exp Biol 41:945-966

48. Nazia S, Haq NB (2011) Removal of uranium. Bio Resour 6(2):2522-2538

49. Naiya TK, Bhattacharya AK, Das SK (2008) Removal of Cd (II) from aqueous solutions using clarified sludge. J Colloid Interface Sci 325(1):48-56. https://doi.org/10.1016/j.jcis.2008.06.003

50. Langmuir I (1918) The adsorption of gases on plane surfaces of glass, mica and platinum. J Am Chem Soc 40(9):1361-1403. https://doi.org/10.1021/ja02242a004
51. Freundlich HZ (1906) Over the adsorption in solution. J Phys Chem 57:385-470

52. Yan G, Viraraghavan T (2003) Heavy-metal removal from aqueous solution by fungus Mucor rouxii. Water Res 37(18):44864496. https://doi.org/10.1016/S0043-1354(03)00409-3

53. Hashim MA, Chu KH (2004) Biosorption of cadmium by brown, green, and red seaweeds. Chem Eng J 97(2-3):249-255. https ://doi.org/10.1016/S1385-8947(03)00216-X

54. Mehrasbi MR, Farahmandkia Z, Taghibeigloo B, Taromi A (2009) Adsorption of lead and cadmium from aqueous solution by using almond shells. Water Air Soil Pollut 199(1-4):343-351. https://doi.org/10.1007/s11270-008-9883-9

55. Ossman ME, Mansour MS (2013) Removal of Cd (II) ion from wastewater by adsorption onto treated old newspaper: kinetic modeling and isotherm studies. Int J Ind Chem 4(1):13. https:// doi.org/10.1186/2228-5547-4-13

56. Yaacoubi H, Zidani O, Mouflih M, Gourai M, Sebti S (2014) Removal of cadmium from water using natural phosphate as adsorbent. Procedia Eng 83:386-393. https://doi.org/10.1016/j. proeng.2014.09.039

57. Dstan L, Dehghani M (2016) Removal of cadmium from industrial waste water by adsorption zeolite clinoptilolite. Biosci Biotechnol Res Commun 9(4):865-871

58. Raad M, Srour M, Hijazi A, Hmedeh R, Damaj Z, Hamieh M, Lami AA, Kassir M, Khatib WE (2017) Removal of cadmium (II) ions from wastewater by adsorption onto the powder of Lebanese Anacyclus nigllifolius Boiss: a comparative study. Am J Phytomed Clin Ther 5:1. https://doi.org/10.21767/2321-2748.100324

59. Jazini R, Soleimani M, Mirghaffari N (2018) Characterization of barley straw biochar produced in various temperatures and its effect on lead and cadmium removal from aqueous solutions. Water Environ J 32(1):125-133. https://doi.org/10.1111/ wej.12307

60. Pavasant $P$, Apiratikul $R$, Sungkhum $V$, Suthiparinyanont $P$, Wattanachira S, Marhaba TF (2006) Biosorption of $\mathrm{Cu}^{2+}, \mathrm{Cd}^{2+}, \mathrm{Pb}^{2+}$, and $\mathrm{Zn}^{2+}$ using dried marine green macroalga Caulerpa lentillifera. Biores Technol 97(18):2321-2329. https://doi.org/10.1016/j.biort ech.2005.10.032

Publisher's Note Springer Nature remains neutral with regard to jurisdictional claims in published maps and institutional affiliations. 